\title{
The Effect of Tax Service Quality on Taxpayer Compliance in Paying Land and Building Tax
}

\author{
Joni, S.S.T, BKP', Handryno, SE, BKP ${ }^{2}$ \\ Institut STIAMI \\ DOI: 10.29322/IJSRP.11.07.2021.p11583 \\ http://dx.doi.org/10.29322/IJSRP.11.07.2021.p11583
}

\begin{abstract}
The purpose of this study is to examine the effect of tax service quality on taxpayer compliance in paying Land and Building Tax in District X. This research is a causative type of research. The population used in this study is all people who are subject to Land and Building Taxpayers in district $\mathrm{X}$. The technique used in sampling is the proportional sampling method, and uses the Slovin formula. The technique used in analyzing the data is multiple regression analysis. The results of the study indicate that the quality of tax services has a significant positive effect on taxpayer compliance. Then a good suggestion for this research is the need for higher quality tax services to improve taxpayer compliance in fulfilling their tax obligations. Future research is expected to use research variables outside those that have been studied in this study.
\end{abstract}

Index Terms- Quality of Tax Service, Taxpayer Compliance

\section{INTRODUCTION}

$\mathrm{W}$ orking on development requires a large amount of funds, both domestic and foreign. The funds needed to invest should preferably come from within the country so that the state debt will decrease, not increase, this is because there are fewer reserves to pay debts. If we don't pay overseas, our country will increasingly be controlled by other countries. The source of the country's income comes from taxes.

Taxes that are included in one of the state revenues that provide the largest contribution to the state budget. The last five years have now contributed to state revenue originating from the taxation sector which still has the possibility to be increased and explore tax potentials that can be developed and optimized with the APBN and then financed with sources of revenue originating from within the country at no cost. dependence on foreign parties in the form of loans from abroad.

Especially in the field of Land and Building Tax, it is one of the central taxes which has the authority to delegate it to the regions. In accordance with the enactment of Law No. 28 of 2009 concerning regional levy taxes and regional taxes, PBB taxes in the urban and rural sectors which are then converted into regional taxes, then the tax calculation will be used as regional income.

The tax subjects in the land and building tax are entities or individuals who actually have rights to the land and have many benefits over the building. Land and building tax is a tax that has potential sources, this is because its object includes all land and building taxes in the territory of the Unitary State of the Republic of Indonesia and has an obligation to pay land and building taxes which are greater than other taxes.

Land and building taxes can be optimized by increasing the compliance of land and building taxpayers. Taxpayer compliance is an obligation in taxation that is disciplined, obedient, has no debt or arrears, and is late in paying taxes. There are several factors that can affect taxpayer compliance, including: the state of the state tax administration system, tax rates, tax audits and enforcement. tax law (Devano and Rahayu, 2006), while factors that come from within are income, experience, understanding (Muslim in Franklin, 2008) and tax awareness factors (Suhardito, 1999).

One effort that aims to improve taxpayer compliance is to provide good service to taxpayers. This good service will come from a good tax officer or tax officer to all taxpayers who will provide a sense of comfort and provide satisfaction for taxpayers which is then expected to increase taxpayer compliance in paying land and building taxes to fulfill their tax obligations. Service quality is a comparison between customer service and the quality of service that consumers expect. Taxpayers will be obedient in fulfilling their tax obligations depending on how tax officials provide the best quality service to their taxpayers. Therefore, tax officers must always improve the quality of their services with the aim of increasing taxpayer compliance by placing taxpayers as customers who must be served as well as possible, such as customers in business organizations. (Sapriadi, 2013).

Service quality has the aim of increasing taxpayer compliance and placing taxpayers as customers who must be served as well as possible, like customers in a business organization. Suyatmin (2004) states that the services provided by the tax authorities to land and building taxpayers include, among others, the determination of land and building taxes, the determination of SPPT, fair as it should be, the tax authorities on tax objections, providing counseling to taxpayers in the field of taxation, especially land and land taxes. building. and ease of paying land and building taxes.

The results of research conducted by Hendrico (2011) are conducting research on the effect of tax service quality, level of understanding, and awareness of taxpayers on taxpayer compliance in paying land and building taxes in district $\mathrm{X}$. The results show that the quality of tax services has a significant positive effect on taxpayer compliance, the level of understanding and awareness of taxpayers has a significant positive effect on taxpayer compliance.

The results of the previous study are the same as the research conducted by Arum (2012) showing that taxpayer 
awareness, tax authorities, and tax sanctions have a positive and significant effect on taxpayer compliance. Furthermore, research conducted by Muliari and Setiawan (2012) states that the perception of tax sanctions and taxpayer awareness has a significant effect on individual taxpayer reporting compliance at the East Denpasar Tax Office. The research conducted is the same as the research conducted by Sapriadi (2013) which states that the quality of tax services, tax sanctions and taxpayer awareness affect taxpayer compliance in paying land and building taxes.

This research is included in the replication of the research conducted by Hendrico which examined the effect of tax service quality on the compliance of land and building taxpayers (District $\mathrm{X})$. The difference in this study is using the variables of tax service quality, tax sanctions, and taxpayer awareness. In addition, this research was conducted in District X.

\section{LITERATURE REVIEW}

\section{Definition of Tax and Taxpayer}

The definition of tax according to Rochmat Soemitro in officials (2011: 1) "Taxes are people's contributions to the state treasury based on the law (which can be enforced) without obtaining counter-achievement that can be shown directly, then used to pay general expenses".

Soeparman Soemahamidjaja states that taxes are mandatory contributions in the form of money or goods that are collected by the authorities based on legal norms, in order to cover the costs of producing collective goods and services in order to achieve general welfare. (Waluyo, 2011: 2). According to Priantara (2009) tax can be interpreted as a contribution to the participation of all members of society to the state. Against these levies, the state does not provide direct contributions to taxpayers. In other words, taxes are contributions paid to the State based on the applicable laws and regulations.

From the explanation above, the characteristics attached to the definition of tax are as follows:

[1] Taxes are collected based on laws and implementing regulations which are enforceable in nature.

[2] Tax payments cannot be demonstrated by the government's individual contradictions.

[3] Taxes are obtained from the state, both central and local governments

[4] The tax is allocated for government spending, if there is still a surplus of the income, then it is used for public investment costs

[5] Taxes have a purpose other than budgetary, namely to regulate.

\section{Tax Function}

Taxes have a function related to the benefits derived from tax collection, there are two tax functions, namely:

1. Set Function (Regular)

Taxes have a function as a tool to regulate and implement policies in the social and economic fields. As a regulatory function, taxes are not only a useful tool to reduce social inequality, but taxes also lead to equity in society, because taxes are carried out indirectly, possibly becoming a burden on public goods.

2. Reception Function (Budgeter)
Taxes as a source of funds needed in government financing and spending. For example, taxes that are included in the APBN are revenues originating from within the country. The function of tax revenue is as a more dominant source of state revenue because the percentage of revenue from this sector is quite large when compared to revenues from other sectors.

Taxes also play a very important role for a country, because taxes are one of the sources of state revenue, which can be used as a tool to regulate economic activities and as an equal distribution of people's income. Taxes have four main functions in economic development, namely as follows (Ahman, 2007: 49):

1. Budgetary Function (Main Source of State Treasury)

Taxes are very relied upon as the main source of government revenue originating from within the country. This can be seen in the APBN because taxes are the largest contributor to state revenue.

2. Allocation Function (Source of Development Financing)

Taxes that have been collected by the state to fill the state treasury (budgeters) are not allowed to just settle in the state treasury. However, it must be allocated to finance development in all fields.

3.Distribution Function (Income Equity Tool)

Taxes collected by the government from taxpayers are used to finance development in all fields. The use of taxes for development costs must be evenly distributed throughout the country so that all citizens, both rich and poor, can enjoy the results of development financed from this tax.

4. Regulatory Function (Tool to Regulate Economic Activities)

Through taxes, the government can regulate economic activities. Through fiscal policy, the government can set high taxes, for example to overcome the inflation rate. The government sees the economy tends to experience a decline (sluggishness), the government can also implement a low tax policy. With low taxes, entrepreneurs will be motivated to increase their investment. If investment increases, employment opportunities will expand and production will increase. In the end, economic growth will be achieved which is currently quite high and the prosperity of the people will increase, and the economy will become stable. The tax setting function is often called the stabilization function.

\section{Taxpayer Compliance}

According to Nurmantu in Devano and Rahayu (2006:110) states that "tax compliance can be interpreted as a condition where taxpayers can fulfill all tax obligations and exercise their tax rights". Meanwhile, according to Nasucha in Devano and Rahayu (2006:111) states that taxpayer compliance can be known from:

a. Taxpayer compliance will then register

b. Compliance in depositing notification letters

c. Suitability for the calculation and payment of tax payable

d. Compliance with arrest payments

Compliance theory has been studied in the social sciences, especially in the fields of psychology and sociology, which emphasizes the importance of the socialization process in influencing an individual's compliance behavior. An individual now tends to obey the law which he considers appropriate and appropriate to his internal norms (Rahayu, 2010). The existence of an administrative sanction and criminal law sanctions for taxpayers who do not fulfill their tax obligations, now the public 
as taxpayers wants to fulfill their obligations. This is related to the issue of tax compliance or tax compliance. Compliance is obedience or discipline, in this case tax compliance is defined as obedience in carrying out all tax regulations.

According to Rahayu (2010), tax compliance can be defined as a condition where taxpayers fulfill all tax obligations and carry out their tax rights. Compliance is also law-abiding behavior. Conceptually, compliance is also defined as an effort to comply with legal regulations by a person or organization. In the self-assessment system, the tax administration plays an active role in carrying out the task of fostering, supervising, and implementing sanctions for delays in fulfilling tax obligations based on the provisions stipulated in tax regulations. The supervisory function also plays a very important role in the selfassessment system, because without supervision in the condition that the level of taxpayer compliance is still low, the system will not work properly, so that taxpayers will carry out their tax obligations incorrectly and ultimately revenue from the tax sector will not will be achieved. There are several factors that can affect the level of taxpayer compliance, including for tax audits and collections. The basics of obedience include: 1) Indotrination. The first reason members of society follow the rules is that they are indoctrinated to do so. Since childhood, humans have been educated to obey the rules that apply in society and other cultural elements. 2) Habituation Since childhood, he has experienced the process of socialization, over time it will become a habit to obey the applicable rules. 3) Utilities Basically, humans have a tendency to live well and orderly, but what is appropriate and orderly for one person is not necessarily appropriate and orderly for another person. Because to require standards of appropriateness and regularity, these standards are guidelines or measures of behavior called rules. Thus, one of the factors that can cause people to obey the rules is because of the usefulness of these rules. 4) Group Identification is one of the reasons why someone is required to obey the rules because this compliance is one of the means to identify themselves with the group. A person obeys the rules that apply in his group not because he thinks his group is more dominant than other groups, but because he wants to identify with his group earlier. Sometimes a person even obeys the rules of another group, because he wants to make identification with that other group.

\section{Tax Service Quality}

Service quality is defined by C.H. Lovelock in Tjiptono $(2005: 258)$ is the level of excellence that can be expected and can be controlled at this level of excellence to meet customer desires. All taxpayers will then comply in fulfilling their tax obligations depending on how the tax officer provides the best quality service to his taxpayers. Therefore, tax officers must always improve the quality of their services with several objectives to improve taxpayer compliance by placing taxpayers as customers who must be served as well as possible. (Sapriadi 2013).

According to the Law of the Republic of Indonesia Number 25 of 2009, tax services are public services. The definition of tax service according to Siregar (in Ardiyansyah, 2016) is the provision of services (serving) the needs of people or the community regarding taxation who have an interest in the organization in accordance with the basic rules and established procedures.
According to Devano and Rahayu (in Resti 2016), service quality is all service activities carried out by the Tax Office as an effort to fulfill the needs of taxpayers in order to implement the provisions of the legislation, which aims to maintain the expected taxpayer satisfaction. to improve taxpayer compliance. Furthermore, according to Fandi Tjiptono 2009 (in Darmkawanto 2015 ) service quality is an effort to fulfill consumer needs and desires with the accuracy of delivery in balancing consumer expectations.

Given the importance of the quality of services that have been provided to taxpayers to improve taxpayer compliance, the Directorate General of Taxes (DGT) has also set excellent service standards that must be implemented in all Tax Service Offices (KPP), both large taxpayers.

According to Parasuraman, et al. in Nugroho and Sumadi (2005), there are five dimensions that can be used in assessing a service quality, namely:

1. Reliability, is the ability to provide services as promised accurately and reliably as expected by customers, which is reflected in timeliness, the same service for many people and without errors.

2. Responsiveness. The agency tries to help and provide a fast service. If you experience failure, then immediately handle the failure in a professional (responsive) manner.

3. Assurance, is the friendliness, knowledge, and ability of employees to carry out tasks spontaneously which ensures good performance so as to create public trust and confidence.

4. Empathy (Emthy). Having a business to understand customer desires by giving sincere and thorough attention to each customer.

5. Physical Form (Tangibility). is a company that can provide tangible evidence at the outset in terms of service quality which is reflected in a reliable physical appearance.

\section{General Standard of Excellent Service}

Standards or basic measures that determine service quality are generally also determined by law, this can be done by collecting expert opinions to be analyzed and produce service standards. Service standards also require the following elements (Purwoko, 2008):

1. Accessibility is a measure of whether this service meets standards that are easily accessible to every customer.

2. Accuracy, a service also wants accuracy and accuracy with the conditions and solutions required.

3. Courtesy, customers do not only want services in the form of goods or services but also must be obtained in a polite and respectful manner.

4. Convenience, solving a problem must be done comfortably so that it is in accordance with its main purpose.

5. Competence, people who carry out services must meet the required qualifications, such as competence, skills, and abilities.

6. Credibility, service officers or institutions must be trusted in meeting service demands from customers.

7. Efficiency, service will be excellent if it is efficient so that there will be no waste. Effectiveness, services must be used to ensure maximum results with simple procedures. 
8. Flexibility, flexibility in service does not have to deviate from the applicable requirements and procedures.

9. Honesty, with honesty a commitment (moral attachment) will be realized with the party to be served.

10. Certainty, provision of service time according to standards.

11. Reliability, substance or content of the service has been tested and is reliable.

12. Responsibility, service must be accounted for by everyone.

13.Security, services obtained must be protected from all risks.

Based on the explanation above, it can be concluded that the quality of service, in this case tax services, can affect the motivation of taxpayers to pay taxes. If the quality of tax services provided by the tax apparatus to taxpayers is very good, then usually it can motivate taxpayers to pay taxes will also be higher.

\section{RESEARCH METHODOLOGY}

This type of research uses explanatory research, namely research that usually emphasizes the relationship between research variables and tests hypotheses that have been formulated previously. In this study, the author will also explain the relationship between the independent variable (independent) and the dependent variable (dependent) to test the existing hypothesis. The research was conducted at the Tax Service Office (KPP). The variables in this study are service quality (X1) and tax sanctions (X2) as independent variables and corporate taxpayer compliance as the dependent variable $(\mathrm{Y})$. The indicators and measurement scales for each of these research variables are as follows:

1. Quality of Service

Service quality is a match between the expectations and desires of service recipients with the reality they receive. The purpose of improving service quality is to create satisfaction for customers. The indicators used in this variable are:a. Reliability (Reliability)

b. Responsiveness

c. Assurance

d. Empathy (Emphaty)

e. Physical form (Tangibility)

2. Taxpayer compliance

It is a condition where the taxpayer fulfills all tax obligations and exercises his taxation rights. The indicators used in this variable are as follows: a. Taxpayer compliance in registering

b. Compliance to re-deposit the notification letter

c. Compliance in calculating and paying taxes payable

d. Compliance in payment of arrears

\section{Types of Data and Data Sources}

Data Type

The type of data used in this study is subject data. Subject data is a type of research data in the form of opinions, attitudes, experiences, or characteristics of a group of people or someone who is the subject of research (respondents).

Data source

The source of data in this study is primary data. Primary data is research data obtained directly from the original source (not through intermediary media). Primary data was also obtained by using a structured questionnaire to gather information with respondents.

The data collection method is

Data collection is done by distributing closed questionnaires to taxpayers. The questionnaire is then given directly to the taxpayer as the respondent and the researcher will take it himself at a predetermined time and the questionnaire must be filled out by the respondent himself.

Research variable

The research variables used in the research used in this study are: dependent variable

The dependent variable in this study is taxpayer compliance in paying land and building taxes.

Independent variable

The independent variable in this study is the quality of tax services Research Instruments

The research instrument used in this study consisted of a questionnaire.

\section{RESULT AND DISCUSSION}

Result

Data analysis

This research has become the independent variable is the quality of tax services, the dependent variable is taxpayer compliance. The following is the descriptive statistical data for each variable:

\section{Table}

\section{Descriptive Statistics}

\begin{tabular}{|l|l|l|l|l|l|}
\hline & N & Minimum & Maximum & Mean & $\begin{array}{l}\text { Std. } \\
\text { Deviation }\end{array}$ \\
\hline Tax Service Quality & 273 & 28.00 & 60.00 & 42.4440 & 3.51764 \\
Taxpayer & 273 & 29.00 & 50.00 & 38.9990 & 3.52800 \\
$\begin{array}{l}\text { Compliance } \\
\text { Valid N (listwise) }\end{array}$ & 273 & & & & \\
\hline
\end{tabular}

Source: SPSS version 15 statistical data analysis (2021)

Based on the table above, of the 273 respondents studied, the Taxpayer Compliance variable $(\mathrm{Y})$ has an average value of 
38.99 with a standard deviation of 3.52. For the Tax Service Quality variable (X1) has an average value of 42.44 with a standard deviation of 3.51 .

According to Nunnaly (1967) in Ghozali (2012: 48), a construct is reliable if it gives a Cronbach Alpha value> 0.07 then the question items that form are reliable. Reliability testing was carried out with the help of the SPSS program.

The $t$ table value at $\alpha 0.05$ is 1.732 . For the tax service quality variable (X1) the t value is 2.048 and the sig value is 0.045 . Thus it can be said that $\mathrm{t}$ count $>\mathrm{t}$ table is $2,236>1,732$ or a significance value of $0.045<\alpha 0.05$. The value of the $\beta$ coefficient of variable $\mathrm{X} 1$ is positive, namely 0.103 . This shows that the quality of tax services (X1) has a significant and positive effect on taxpayer compliance.

\section{Discussion \\ The Effect of Service Quality on Taxpayer Compliance.}

Given the importance of the quality of tax services which are then provided to taxpayers to improve taxpayer compliance, the Directorate General of Taxes (DGT) has been established with one of its visions and missions to realize excellent service in all Tax Service Offices (KPP), both large and large taxpayers. intermediate taxpayer. Medium Taxpayer. and KPP Pratama as confirmed in the circular letter of the Directorate General of Taxes no. SE-45/PJ/2007.

The task of providing tax services to taxpayers is the main door in the Tax Service Office which is included as an Integrated Service Place, namely a tax service place that has been integrated with the existing system. In this excellent service, the standard of service that must be provided to taxpayers is stated, which includes the service schedule and the type of service which is then provided to the taxpayer, the standard of facilities that must be owned by the Tax Office and officers or human resources who have hard and soft competencies and as ethical requirements. standard.

The results of research conducted by Arum (2012) state that the tax authorities have a significant and positive effect on taxpayer compliance in paying land and building taxes.

\section{CONCLUSIONS AND SUGGESTIONS}

\section{Conclusion}

Based on the results of the research above, it can be concluded that the quality of service simultaneously has a significant effect on taxpayer compliance. The ability to pay taxes is $45 \%$, while the remaining $55 \%$ is influenced by other variables that are not included in this research model. This research can also be included in this research model.

This research can be used as input for the Director General of Taxes which is useful for supervising and monitoring and evaluating tax services, then import duties are served by taxpayers to fulfill tax obligations and pay attention and ensure all infrastructure facilities will be managed properly. as regulated in detail in accordance with excellent service standards.

\section{Suggestion}

The tax directorate general imposes sanctions on people who do not pay taxes so that they become aware of paying taxes.

\section{REFERENCES}

[1] Alabede, J. O., \& Zainal Affrin, Z. (2011). Tax service quality and compliance behaviour in Nigeria: Do taxpayer's financial condition and risk preference play any moderating role?. European Journal of Economics, Finance and Administrative Sciences, (35), 90-108.

[2] Al-Ttaffi, L. H. A., \& Abdul-Jabbar, H. (2016). Service quality and income tax non-compliance among small and medium enterprises in Yemen. Journal of Advanced Research in Business and Management Studies, 4(1), 12-21.

[3] Arum (2012), The Influence of Taxpayer Awareness, Fiskus Services, and Tax Sanctions on Individual Taxpayer Compliance Conducting Business Activities and Free Work

[4] Christensen, A. L. (1992). Evaluation of tax services: A client and preparer perspective. The Journal of the American Taxation Association, 14(2), 60.

[5] Devano, Sony and Rahayu, Siti Kurnia.(2006). Taxation Concepts, Theories and Issues. Kencana Publisher: Jakarta

[6] Downes, T. A., \& Figlio, D. N. (1999). Do tax and expenditure limits provide a free lunch? Evidence on the link between limits and public sector service quality. National Tax Journal, 113-128.

[7] Law Number 25 of 2009 concerning Public Services www.legalitas.org/inclphp/buka.php?d...9...uu25-2009.

[8] Muliari, Ni Ketut and Setiawan, Putu Ery.(2012). The Influence of Perceptions About Tax Sanctions and Taxpayer Awareness on Taxpayer Reporting Compliance

[9] Mustapha, B., \& Obid, S. N. B. S. (2015). Tax service quality: The mediating effect of perceived ease of use of the online tax system. Procedia-Social and Behavioral Sciences, 172, 2-9.

[10] Myers, M., \& Morris, L. J. (1998). A gap analysis of a CPA tax service and the implications for enhancing service quality. Journal of Customer Service in Marketing \& Management, 5(1), 27-47.

[11] Nugroho, Andi Setijo and Sumadi (2005). The Effect of Service Quality on Taxpayer Satisfaction: Study on Income Tax Objects at KPP Yogyakrta Satu, Synergy Journal Business and Management Studies.

[12] Official, Siti (2012). Taxation theory and cases. Salemba Empat: Jakarta

[13] Resti, Devi and Harry Soesanto. 2016. The Effect of Price Perception, Service Quality through Customer Satisfaction on Repurchase Interest at Sifra Beauty House in Pati. Journal of management. 5 (1): 1-12

[14] Sapriadi, Doni (2013), The Influence of Tax Service Quality, Tax Sanctions and Taxpayer Awareness of Taxpayer Compliance in Paying Land and Building Tax (In Selupu Rejang District)

[15] Savitri, E. (2015). The effect of tax socialization, tax knowledge, expediency of tax ID number and service quality on taxpayers compliance with taxpayers awareness as mediating variables. Procedia-social and behavioral sciences, 211, 163-169.

[16] Tjiptono, F (2005), Total Quality Service Principles, Yogyakarta: Andi Offset.

\section{AUTHORS}

First Author - Joni, S.S.T, BKP, Institut STIAMI, joni.jovindo@gmail.com

Second Author - Handryno, SE, BKP, Institut STIAMI, Handryno@yahoo.com 
